\title{
ALIRAN ILMU NEGARA MENURUT ALIRAN LIBERALISME
}

\author{
NAMA : SYAHRUL RAMADHAN \\ EMAIL : syrn3012@gmail.com \\ NO BP : 1810095600046 \\ SEKOLAH TINGGI ILMU HUKUM PADANG
}

\section{BAB I}

\section{PENDAHULUAN}

\section{A. Latar Belakang}

Aliran-aliran dalam Ilmu Negara, adalah paham-paham atau pendapat-pendapat yang pada suatu waktu dalam perkembangan sejarah manusia mempunyai pengaruh besar terhadap ketatanegaraan. Untuk menguraikan paham-paham dalam Ilmu Negara mesti dimulai dari paham yang paling kuno, yaitu paham jaman Yunani Kuno. Salah satu aliran dalam ilmu Negara yaitu aliran liberalism

\section{B. Rumusan Masalah}

1. sebutkan dan jelaskan apa yang dimaksud aliran liberalisme

2. sebutkan dan jelaskan sejarah, ciri-ciri, contoh dan penerapan aliran liberalisme. 


\section{Tujuan}

1.untuk menyelesaikan tugas uas makalah mata kuliah ilmu Negara.

2.untuk mengetahui apa itu aliran liberalism

3.untuk mengetahui sejarah, ciri-ciri, contoh dan penerapan aliran liberalism

BAB II

\section{PEMBAHASAN}

\section{A. Aliran liberalism}

Istilah liberalisme berasal dari bahasa Latin, libertas atau dalam bahasa Inggris disebut liberty yang artinya kebebasan. Liberalisme adalah suatu paham yang menghendaki adanya kebebasan. Kebebasan yang dimaksud adalah kebebasan untuk bertempat tinggal, kemerdekaan pribadi, hak untuk menentang penindasan, serta hak untuk mendapatkan perlindungan pribadi dan hak milik.

Selain itu, liberalisme juga didefinisikan sebagai suatu paham yang menghendaki adanya kebebasan individu, baik dalam bidang ekonomi, politik, ilmu pengetahuan, kebudayaan, agama, maupun kebebasan sebagai warga Negara dinamakan liberalisme.

Paham liberal maupun sebagai reaksi atas penindasan yang dilakukan oleh kaum bangsawan dan agamawan pada masa perkembangan feodalisme dengan pemerintahan monarki absolute. Pendukung utama paham liberal adalah kaum borjuis dan kaum-kaum terpelajar kota. 


\section{B. Sejarah ideology liberalism}

paham liberalisme mulai berkembang di pada abad ke-18 dan 19 di Prancis dan Inggris. Sebagai suatu gerakan, liberalisme dimulai pada masa renaissance yang memperjuangkan kebebasan manusia dari kungkungan gereja atau agama. Saat itu, kekuasaan raja, bangsawan, dan gereja mendominasi seluruh kehidupan masyarakat.

Rakyat tidak memiliki kebebasan dalam berpendapat dan bertindak. Keadaan tertekan ini menimbulkan kritik dari berbagai kalangan yang menginginkan kebebasan di semua bidang kehidupan. konsep kebebasan dalam bidang politik melahirkan pemikiran tentang negara yang demokrasi. Konsep bebas dalam bidang ekonomi membuat masyarakat menentang monopoli dan campur tangan pemerintah, rakyat menginginkan ekonomi bebas. Dalam bidang moral, liberalisme menjunjung tinggi kebebasan individu dan menentang otoriterisme.

Dalam bidang agama, kaum liberal menginginkan kebebasan memilih agama sesuai dengan keyakinannya, bebas beribadah menurut agamanya, dan juga bebas untuk tidak menganut agama apapun. Yang mana, urusan agama tidak boleh dicampur dengan urusan pemerintahan. Beberapa tokoh yang mengusung terjadinya liberalisme dalam kehidupan saat itu, antara lain Voltaire, Montesquieu, dan Rousseau. Salah satu peristiwa yang menjadi tanda lahirnya liberalisme di Eropa ialah Revolusi Industri di Inggris (1760-1840) dan Revolusi Perancis (17891815). 


\section{Ciri-ciri Liberalisme}

Mengutip kembali dari Dwi Siswanto (Jurnal Filsafat, Vol. 38, 2004: 271), disebutkannya ada lima ciri liberalisme, yaitu:

1. Bentuk pemerintahan demokrasi adalah yang terbaik.

2. Masyarakat memiliki kebebasan intelektual penuh.

3. Pengaturan yang dilakukan pemerintah hanya terbatas.

4. Kekuasaan seseorang diartikan sebagai hal buruk dalam kehidupan.

5. Kebahagiaan individu adalah tujuan utama.

Sementara itu, Heru Susanto membagi ciri-ciri liberalisme dalam beberapa bidang, antara lain sebagai berikut:

1. Bidang Politik: Munculnya demokratisasi.

2. Bidang Sosial: Kebebasan berpendapat, kesamaan kesempatan dalam usaha, reformasi sosial, dan perasaan egaliter.

3. Bidang Seni dan Budaya: Kebebasan dalam berekspresi, seperti lukisan, drama, seni, musik, dan lain-lain.

4. Bidang Ekonomi: Ekonomi pasar yang demokratis.

\section{Contoh dan Penerapan Liberalisme}

Masih dari Heru Susanto, ia menuturkan dalam penelitiannya bahwa pengaruh atau praktik liberalisme yang berjalan dan berdampak bagi kehidupan saat ini adalah munculnya globalisasi.

Secara garis besar, dapat dipahami bahwa globalisasi mengintroduksikan pasar bebas, hiperliberalisasi individu, dan berupaya mengurangi peran pemerintah dalam sektor ekonomi. 
Di Indonesia, sistem liberalisme tidak diterapkan dalam kehidupan politik, tetapi diterapkan dalam kehidupan ekonomi.

Berdasarkan pandangan Heru Susanto, pengaruh itu tampak pada berkembangnya gaya hidup penduduk yang mengikuti zaman. Hal tersebut dapat dilihat dari gaya hidup mewah dan kebebasan dalam hal memilih kebutuhan merupakan ciri-ciri liberalisme dalam sektor ekonomi. Selain itu,

pengaruh liberalisme juga dapat dilihat di beberapa negara besar seperti Amerika Serikat, Perancis, dan Jerman. Di negara-negara tersebut, liberalisme sangat dijunjung tinggi. Hal tersebut dapat dilihat dari penerapan demokrasi yang membuat rakyat bebas berpendapat dan berekspresi. Kemudian, dapat dilihat dari sektor ekonomi yang menerapkan prinsip sistem ekonomi pasar demokratis.

\section{BAB III PENUTUP}

\section{A. KESIMPULAN}

Dari uraian tersebut diatas dapat maka kami sebagai penulis dapat menarik kesimpulan yakni :

paham liberalisme mulai berkembang di pada abad ke-18 dan 19 di Prancis dan Inggris. Sebagai suatu gerakan, liberalisme dimulai pada masa renaissance yang memperjuangkan kebebasan manusia dari kungkungan gereja atau agama. Saat itu, kekuasaan raja, bangsawan, dan gereja mendominasi seluruh kehidupan masyarakat.

paham liberalisme mulai berkembang di pada abad ke-18 dan 19 di Prancis dan Inggris. 
Sebagai suatu gerakan, liberalisme dimulai pada masa renaissance yang memperjuangkan

kebebasan manusia dari kungkungan gereja atau agama. Saat itu, kekuasaan raja, bangsawan, dan gereja mendominasi seluruh kehidupan masyarakat.

Dan juga terdapar beberapa ciri-ciri liberalisme dalam beberapa bidang, antara lain sebagai berikut:

1. Bidang Politik: Munculnya demokratisasi.

2. Bidang Sosial: Kebebasan berpendapat, kesamaan kesempatan dalam usaha, reformasi sosial, dan perasaan egaliter.

3. Bidang Seni dan Budaya: Kebebasan dalam berekspresi, seperti lukisan, drama, seni, musik, dan lain-lain.

4. Bidang Ekonomi: Ekonomi pasar yang demokratis.

\section{B. PENUTUP}

Kami sepenuhnya menyadari akan kekurangan dan keterbatasan dari pengetahuan kami dalam menyusun materi-materi yang tersuguh didalam makalah ini. Saran serta kritik yang membangun tentunya sangat kami harapkan sebagai perbaikan-perbaikan dikemudian hari. Besar Harapan kami makalh ini dapat difahami dan kemudian bermanfaat bagi pembaca dan khusunya bagi kami penyusun. Amiin. 


\section{DAFTAR PUSTAKA}

Darmini Roza dan Laurensius Arliman S, Peran Pemerintah Daerah Di Dalam Melindungi Hak Anak Di Indonesia, Masalah-Masalah Hukum, Volume 47, Nomor 1, 2018. https://doi.org/10.14710/mmh.47.1.2018.10-21

Laurensius Arliman S, Peranan Metodologi Penelitian Hukum di Dalam Perkembangan Ilmu Hukum di Indonesia, Soumatera Law Review, Volume 1, Nomor 1, 201. http://doi.org/10.22216/soumlaw.v1i1.3346.

Laurensius Arliman S, Peran Badan Permusyawaratan Desa di Dalam Pembangunan Desa dan Pengawasan Keuangan Desa, Padjadjaran Journal of Law, Volume 4, Nomor 3, 2017. https://doi.org/10.15408/jch.v4i2.3433.

Laurensius Arliman S, Penanaman Modal Asing Di Sumatera Barat Berdasarkan UndangUndang Nomor 25 Tahun 2007 Tentang Penanaman Modal, Supremasi Hukum, Volume 1, Nomor 1, 2018. http://dx.doi.org/10.36441/hukum.v1i01.102 .

Laurensius Arliman S, Memperkuat Kearifan Lokal Untuk Menangkal Intoleransi Umat Beragama Di Indonesia, Ensiklopedia of Journal, Volume 1, Nomor 1, 2018, https://doi.org/10.33559/eoj.v1i1.18.

Laurensius Arliman S, Perkawinan Antar Negara Di Indonesia Berdasarkan Hukum Perdata Internasional, Kertha Patrika, Volume 39, Nomor 3, 2017, https://doi.org/10.24843/KP.2017.v39.i03.p03. 
Laurensius Arliman S, Partisipasi Masyarakat Di Dalam Pengelolaan Uang Desa PascaUndangUndang Nomor 6 Tahun 2014 Tentang Desa, Jurnal Arena Hukum, Volume 12, Nomor 2, 2019, https://doi.org/10.21776/ub.arenahukum.2019.01202.5.

Laurensius Arliman S, Mewujudkan Penegakan Hukum Yang Baik Di Negara Hukum Indonesia, Dialogica Jurnalica, Volume 11, Nomor 1, 2019, https://doi.org/10.28932/di.v11i1.1831.

Laurensius Arliman S, Mediasi Melalui Pendekatan Mufakat Sebagai Lembaga Alternatif Penyelesaian Sengketa Untuk Mendukung Pembangunan Ekonomi Nasional, UIR Law Review, Volume 2, Nomor 2, 2018, https://doi.org/10.25299/uirlrev.2018.vol2(02).1587

Laurensius Arliman S, Peranan Filsafat Hukum Dalam Perlindungan Hak Anak Yang Berkelanjutan Sebagai Bagian Dari Hak Asasi Manusia, Doctrinal, Volume 1, Nomor 2,2016.

Laurensius Arliman S, Ni Putu Eka Dewi, Protection of Children and Women's Rights in Indonesiathrough International Regulation Ratification, Journal of Innovation, Creativity and Change Volume 15, Nomor 6, 2021.

Laurensius Arliman S, Gagalnya Perlindungan Anak Sebagai Salah Satu Bagian Dari Hak Asasi Manusia Oleh Orang Tua Ditinjau Dari Mazhab Utilitarianisme, Jurnal Yuridis, Volume 3, Nomor 2, 2016, http://dx.doi.org/10.35586/.v3i2.180.

Laurensius Arliman S, Tantangan Pendidikan Kewarganegaraan Pada Revolusi 4.0, Jurnal Ensiklopedia Sosial Review, Volume 2, Nomor 3, 2020.. 